\title{
Effects of Water Level Fluctuation on Waterbirds Distribution and Aquatic Vegetation Composition at Natural Wetland Reserve, Peninsular Malaysia
}

\author{
Muhammad Nawaz Rajpar ${ }^{1}$ and Mohamed Zakaria ${ }^{2}$ \\ ${ }^{1}$ Forest Education Division, Pakistan Forest Institute, 25130 Peshawar, Pakistan \\ ${ }^{2}$ Faculty of Forestry, Universiti Putra Malaysia, 43400 UPM Serdang, Selangor Darul Ehsan, Malaysia \\ Correspondence should be addressed to Mohamed Zakaria, mzakaria@putra.upm.edu.my
}

Received 23 May 2011; Accepted 14 July 2011

Academic Editors: C. Jarnevich and D. C. Moon

Copyright (C) 2011 M. N. Rajpar and M. Zakaria. This is an open access article distributed under the Creative Commons Attribution License, which permits unrestricted use, distribution, and reproduction in any medium, provided the original work is properly cited.

\begin{abstract}
The effects of water level fluctuations on waterbirds distribution and aquatic vegetation composition was determined using distance sampling point count method and direct visual observation at Paya Indah Natural Wetland Reserve, Peninsular Malaysia. A total of 2563 waterbird individual of 28 species and 8 families were detected in three habitats, that is, marsh swamp (68.59\%), open water body (18.42\%), and lotus swamp (12.99\%). Porphyrio porphyrio was the most dominant species in marsh swamp (45.39\%), and lotus swamp (23.42\%), whereas Dendrocygna javanica (42.16\%) was the most abundant in open water body. The highest water level for marsh swamp $(2.313 \mathrm{~m})$ and lotus swamp $(2.249 \mathrm{~m})$ was recorded in January, 2008 and for open water body $(2.572 \mathrm{~m})$ in January and April, 2008. In contrast, the lowest water level for marsh swamp (2.048 $\mathrm{m})$ and lotus swamp $(1.834 \mathrm{~m})$ was determined in October, 2008 and for open water body $(2.398 \mathrm{~m})$ in January, 2009. Pearson test indicates weak linear correlationship between water level and waterbird abundance in lotus swamp habitat $\left(r^{2}=0.120, P>0.05\right)$ and in marsh swamp $\left(r^{2}=0.100, P>0.05\right)$ and negative linear correlationship $\left(r^{2}=-0.710, P>0.05\right)$ in open water body habitat. Canonical correspondence analysis indicated strong correlationship between waterbird abundance and vegetation (73.0\%) in open water body, and weaker association (29.8\%) in lotus swamp. The results of this study indicate that water level is a major factor that influences the relative abundance and distribution of ducks, swamphen, crakes, herons, jacanas, and moorhens directly and indirectly. In addition, it also effects on the dynamics of aquatic vegetation composition such as, emergent, submerged, and grasses in this wetland reserve.
\end{abstract}

\section{Introduction}

Malaysia is rich in aquatic resources such as rivers, lakes, reservoirs, swamps, mangroves, estuaries, lagoons, and the sea. These aquatic resources provide diverse habitats for wildlife species particularly waterbirds and are lifeline for Malaysian people that supply diverse food resources and water for domestic, agriculture, and industrial uses. Majority of people live within the vicinity of aquatic resources. Despite their crucial role, these aquatic resources are facing overwhelming pressure such as siltation, water pollution, loss of mangrove, and degradation of coral reef [1].

"Waterbirds" refers to the bird species that entirely depend on wetlands for a variety of activities such as foraging, nesting, loafing, and moulting [2]. They are bioindicators of wetland ecosystems, because they quickly respond to any changes in vegetation composition and water level fluctuation as compared to other animals $[3,4]$. Water level among wetlands always fluctuates from time to time depending upon location, precipitation, and incoming water resources. Single wetlands will not have similar attraction to waterbirds throughout the year or among years due to unpredictable fluctuation in water level that causes changes in aquatic vegetation composition.

It has been reported that fluctuation in water level influenced the distribution of waterbirds such as from total drought [5-7] to major flooding $[8,9]$. The highest species richness and density of waterbirds occurs in reed beds of 
aquatic vegetation, where the water level is $20-65 \mathrm{~cm}$ in depth [10].

Determining the population fluctuation of waterbirds in wetland habitats is highly important to understand the waterbird community structures and population status of existing species in the dwelling areas [11] For this reason, the distance sampling point count method is one of the most common quantitative survey techniques that have been widely used in order to monitor the correlationship of the avian species with water level and vegetation composition [12]. This method involves the visual and auditory detection of birds at a preselected spot for specific period of time [13-15].

Very little information is available on the effects of water level fluctuation on waterbird distribution and aquatic vegetation composition in Malaysia. The main objective of this study was to determine and understand the effects of water level fluctuations on waterbirds distribution and aquatic vegetation composition in Paya Indah Natural Wetland Reserve, Peninsular Malaysia.

\section{Materials and Methods}

2.1. Study Site. Paya Indah Natural Wetland Reserve encompasses 3050 ha out of which 450 ha are under the administration of the Department of Wildlife and National Parks, Peninsular Malaysia. The study area is located within the quadrant of $101^{\circ} 10^{\prime}$ to $101^{\circ} 50^{\prime}$ longitude and $2^{\circ} 50^{\prime}$ and $3^{\circ} 00^{\prime}$ latitude (see Figure 1). This natural wetland reserve comprises three major aquatic habitats that may vary in vegetation composition and structure, namely, (i) marsh swamp (ii) lotus swamp, and (iii) open water body.

2.2. Marsh Swamp. These are shallow watery areas densely covered by emergent aquatic vegetation, that is, Eleocharis dulcis, Lepironia articulata, Scirpus olneyi, Carex sp., Elodea, Spartina alterniflora, Scleria purpurascens, Philydrum lanuginosum, Panicum maximum, and Lycopodium cenum. The marsh swamps are rich in fishes, amphibians, and aquatic invertebrate assemblages (Figure 2).

2.3. Lotus Swamp. The water surface is dominated by Nelumbo nucifera, and N. nouchali, N. pubescens and edges covered by E. Dulcis and L. articulate and somewhere by Phragmites karka and Typha angustifolia (Figure 3).

2.4. Open Water Body. These are deep water areas dominated by submerged vegetation (i.e., Myriophyllum spicatum, Salvinia minima, Potamegoton sp., Salvinia sp., S. purpurascens, and S. alterniflora) and are rich in food resources such as fishes, amphibians and aquatic invertebrates, as it provides suitable breeding sites for them (Figure 4).

2.5. Waterbird Surveys. Waterbird surveys were carried out using the distance sampling point count method to determine the species composition, relative abundance, and habitat preference from November, 2007 to January, 2009. One hundred and twenty-one point count stations at $300 \mathrm{~m}$ interval apart from each other were established within marsh swamp (43 stations), lotus swamp (38 stations) and open water body (40 stations) (Figure 5). The main reason of using $300 \mathrm{~m}$ interval apart was to avoid double counting of the same waterbirds at more than one station. The survey was done fifteen times at monthly interval in order to obtain reliable results and avoid bias. The repetition increased the precision and provided accurate estimates. The survey was carried out early in the morning, that is, $0730-1100 \mathrm{hrs}$. The detections of birds within each point count station were done for 10 minutes. During each survey, all waterbird species and individuals seen or heard were recorded. The flushed waterbirds with unknown original position were not included in the analysis. The methodology was followed as described by Smith et al. [16], Petit et al. [17], Buckland et al. [18], Aborn [19], and Nadeau et al. [20].

2.6. Water Level. The water levels in the three habitats, namely, marsh swamp, open water body, and lotus swamp for a period of 15 consecutive months from November, 2007 to January, 2009, was obtained from Department of Irrigation, Malaysia, in order to determine and understand the fluctuation of water level and its effects on the waterbird distribution and aquatic vegetation at Paya Indah Wetland Reserve, Peninsular Malaysia. The water level was recorded in feet; later on, feet were converted into meters.

2.7. Vegetation Survey. The vegetation proportion (\%) and type such as emergent, submerged, grasses, shrubs, and trees in marsh swamp, lotus swamp, and open water body was determined by direct observation within the consistency of the point count stations.

2.8. Data Analysis. The relative abundance (\%) of waterbird species was determined using the following expression:

$$
\frac{n}{N} \times 100
$$

where $n=$ number of a particular waterbird species and $N=$ total observations detected for all species.

The effects of water level fluctuation on waterbird distribution and aquatic vegetation composition were determined by direct observation. In addition, the correlationship between water level and waterbird relative abundance was determined using Pearson's correlation coefficient in order to understand the effects of water level on waterbird distribution

$$
r=\frac{\sum_{i=1}^{n}\left(X_{i}-\bar{X}\right)\left(Y_{i}-\bar{Y}\right)}{\sqrt{\sum_{i=1}^{n}\left(X_{i}-\bar{X}\right)^{2}} \sqrt{\sum_{i=1}^{n}\left(X_{i}-\bar{Y}\right)^{2}}},
$$

where $X_{i}=$ standard score, $\bar{X}=$ sample mean, and $S_{X}=$ standard deviation.

The correlationship between waterbirds and vegetation was examined using multiple regressions, that is, canonical correspondence analysis (CCA) software (version 4.5) by Ter Braak and Smilauer [21] to understand the correlationship between aquatic vegetation composition and waterbird abundance. 


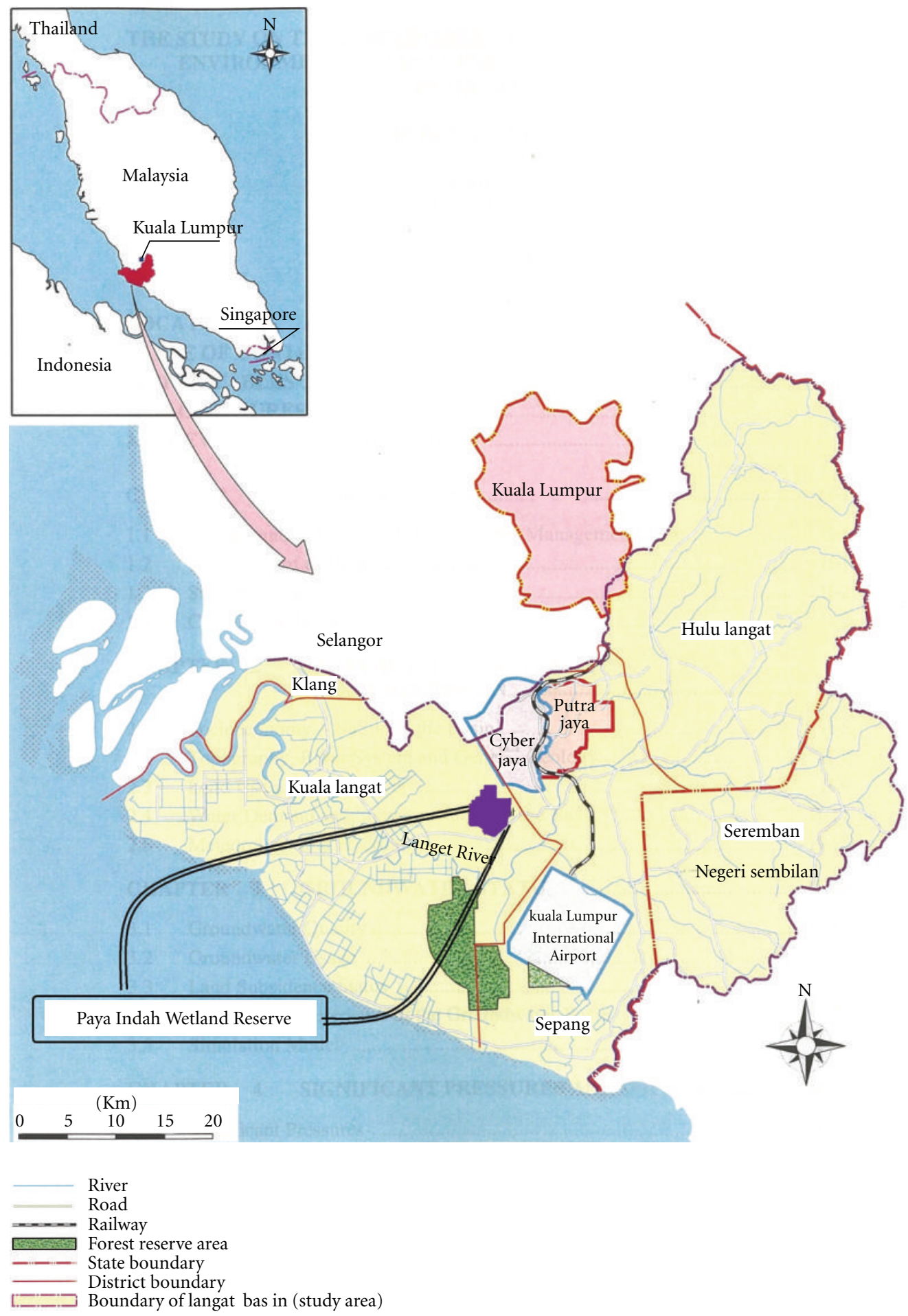

Figure 1: Location map of Paya Indah Natural Wetland Reserve, Selangor, Peninsular Malaysia.

The results were compared using analysis of variance (ANOVA) and Tukey's (HSD) test to determine the significant difference of water level and species abundance among three habitats, that is, marsh swamp, lotus swamp, and open water body.

\section{Results}

A total of 2563 waterbird individual of 28 species and 8 families were recorded in three habitats, namely marsh swamp $(68.59 \%)$, open water body $(18.42 \%)$, and lotus swamp 


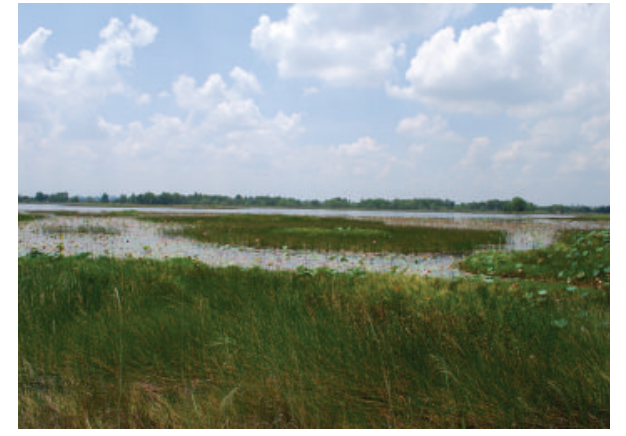

Figure 2: Marsh swamp habitat at Paya Indah Natural Wetland Reserve, Peninsular Malaysia.

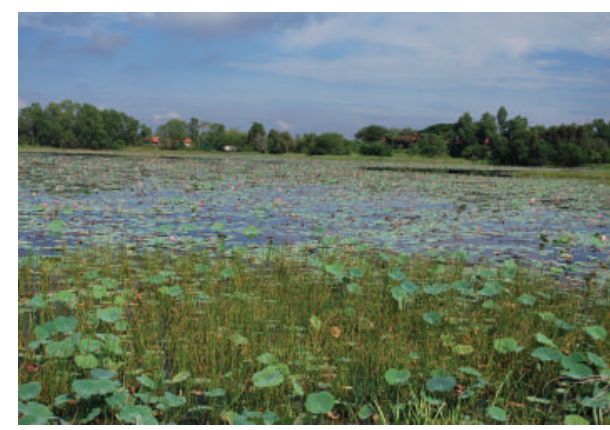

Figure 3: Lotus swamp habitat at Paya Indah Natural Wetland Reserve, Peninsular Malaysia.

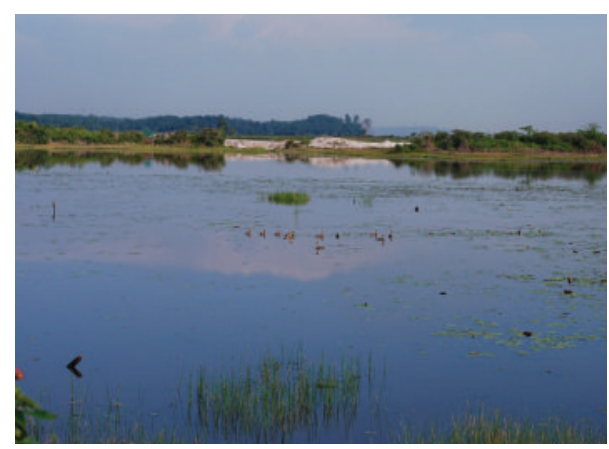

Figure 4: Open water body habitat at Paya Indah Natural Wetland Reserve, Peninsular Malaysia.

(12.99\%) using distance sampling point count method at Paya Indah Natural Wetland Reserve, Peninsular Malaysia.

\subsection{Relative Abundance of Waterbirds in Marsh Swamp. Marsh} swamp habitat was most attractive habitat for waterbirds, that is, a total of 1758 waterbird individuals of 22 species and 8 families were recorded using distance sampling point count method. Purple swamphen-Porphyrio porphyrio (45.39\%), white-breasted waterhen-Amaurornis phoenicurus (11.38\%), purple heron-Ardea purpurea (9.33\%), and yellow bittern-Ixobrychus sinensis (9.22\%) were four of the most abundant waterbird species with highest relative abundance. On the contrary, pheasant-tailed jacana-Hyd- rophasianus chirurgus was the rarest waterbird species observed only once $(0.06 \%)$ during survey period (Table 1$)$.

3.2. Relative Abundance of Waterbirds in Lotus Swamp. Point count method detected 333 waterbird individuals of 17 species and 8 families in the lotus swamp habitat. Three waterbird species, namely, purple swamphenPorphyrio porphyrio (23.42\%), purple heron-Ardea purpurea $(15.62 \%)$, and white-throated kingfisher-Halcyon smyrnensis (15.32\%) were the most dominant in lotus swamp habitat. In cotrast, common kingfisher (Alcedo atthis), cotton pygmy goose (Nettapus coromandelianus), and water cock (Gallicerx cinerea) were the rarest waterbird species, which were recorded only once $(0.30 \%$ each) (Table 2$)$.

3.3. Relative Abundance of Waterbirds in Open Water Body. A total of 472 waterbird individuals that belong to 15 bird species and 7 families were recorded in the open water body habitat using the point count method. The results indicated that lesser whistling duck-Dendrocygna javanica (42.16\%), cotton pygmy goose-Nettapus coromandelianus (17.16\%), and white-throated kingfisher-Halcyon smyrnensis (8.90\%) were the three most dominant waterbird species in the open water body area. On the contrary, Grey heron (Ardea cinerea) and schrenck's bittern (Ixobrychus eurhythmus) were the two rarest waterbirds, which were recorded only once $(0.21 \%$ each) (Table 3).

The significant difference for waterbird abundance among the three habitats, that is, marsh swamp, open water body, and lotus swamp, was compared by applying the oneway analysis of variance (ANOVA) and Tukey's (HSD) test. The ANOVA test indicated that the waterbird abundance of marsh swamp habitat during 15 consecutive months was significantly different from lotus swamp and open water body habitats, that is, $F_{2,42}=226.20, P<0.05$ (Table 4 and Table 13).

3.4. Water Level in Marsh Swamp. The results showed that the water level in the marsh swamp habitat varied among 15 consecutive months due to the variation in rainfall volumes and discharge water from the catchment areas of Sungai Chua and Sungai Bisa. Notably, the highest water level was recorded in January, 2008 (i.e., $2.313 \mathrm{~m}$ ), and the lowest was detected in October, 2008 (i.e., $2.048 \mathrm{~m}$ ) (Table 5).

3.5. Water Level in Open Water Body. Higher water level, that is, $2.572 \mathrm{~m}$, was recorded in during January and April, 2008. In contrast, lower water level, that is, $2.398 \mathrm{~m}$, was observed in January, 2009 due to low rainfall (Table 6).

3.6. Water Level in Lotus Swamp. Apparently, the highest water level (i.e., $2.249 \mathrm{~m}$ ) for lotus swamp habitat was recorded in January, 2008, and the lowest (i.e., $1.834 \mathrm{~m}$ ) was recorded in October, 2008 (Table 7).

The significant difference for mean water level among the three habitats, that is, marsh swamp, open water body, and lotus swamp, was compared by applying the one-way analysis of variance (ANOVA) and Tukey's (HSD) test. The ANOVA analysis indicated that the water level of the three habitats 
TABLE 1: List of waterbird species with relative abundance recorded in Marsh Swamp at Paya Indah Natural Wetland Reserve, Peninsular Malaysia.

\begin{tabular}{|c|c|c|c|c|c|}
\hline Rank & Family name & Common name & Scientific name & No. of observations & $\%$ \\
\hline 1 & Rallidae & Purple swamphen & Porphyrio porphyrio & 798 & 45.39 \\
\hline 2 & Rallidae & White-breasted waterhen & Amaurornis phoenicurus & 200 & 11.38 \\
\hline 3 & Ardeidae & Purple heron & Ardea purpurea & 164 & 9.33 \\
\hline 4 & Ardeidae & Yellow bittern & Ixobrychus sinensis & 162 & 9.22 \\
\hline 5 & Alcidinidae & White-throated kingfisher & Halcyon smyrnensis & 128 & 7.28 \\
\hline 6 & Charadriidae & Red-wattled lapwing & Vanellus indicus & 93 & 5.29 \\
\hline 7 & Rallidae & Common moorhen & Gallinula chloropus & 61 & 3.47 \\
\hline 8 & Anatidae & Lesser whistling duck & Dendrocygna javanica & 37 & 2.10 \\
\hline 9 & Ardeidae & Cinnamon bittern & Ixorbychus cinnamoneus & 28 & 1.59 \\
\hline 10 & Ardeidae & Little heron & Butorides striatus & 20 & 1.14 \\
\hline 11 & Ardeidae & Black-crowned nightheron & Nycticorax nycticorax & 13 & 0.74 \\
\hline 12 & Anatidae & Cotton pygmy goose & Nettapus coromandelianus & 11 & 0.63 \\
\hline 13 & Scolopacidae & Pintail snipe & Gallinago stenura & 10 & 0.57 \\
\hline 14 & Ardeidae & Grey heron & Ardea cinerea & 7 & 0.40 \\
\hline 15 & Ardeidae & Schrenck's bittern & Ixobrychus eurhythmus & 6 & 0.34 \\
\hline 16 & Ardeidae & Great egret & Egretta albus & 4 & 0.23 \\
\hline 17 & Ardeidae & Little egret & Egretta garzetta & 4 & 0.23 \\
\hline 18 & Rallidae & Water cock & Gallicerx cinerea & 4 & 0.23 \\
\hline 19 & Rallidae & Ballion's crake & Porzana pusilla & 3 & 0.17 \\
\hline 20 & Alcidinidae & Common kingfisher & Alcedo atthis & 2 & 0.11 \\
\hline 21 & Podicipedidae & Little grebe & Tachybaptus ruficollis & 2 & 0.11 \\
\hline \multirow[t]{2}{*}{22} & Jacanidae & Pheasant-tailed jacana & Hydrophasianus chirurgus & 1 & 0.06 \\
\hline & & Total & & 1758 & \\
\hline
\end{tabular}

TABle 2: List of waterbird species with relative abundance recorded in Lotus Swamp at Paya Indah Natural Wetland Reserve, Peninsular Malaysia.

\begin{tabular}{|c|c|c|c|c|c|}
\hline Rank & Family name & Common name & Scientific name & No. of observations & $\%$ \\
\hline 1 & Rallidae & Purple swamphen & Porphyrio porphyrio & 78 & 23.42 \\
\hline 2 & Ardeidae & Purple heron & Ardea purpurea & 52 & 15.62 \\
\hline 3 & Alcidinidae & White-throated kingfisher & Halcyon smyrnensis & 51 & 15.32 \\
\hline 4 & Ardeidae & Yellow bittern & Ixobrychus sinensis & 42 & 12.61 \\
\hline 5 & Rallidae & White-breasted waterhen & Amaurornis phoenicurus & 38 & 11.41 \\
\hline 6 & Rallidae & Common moorhen & Gallinula chloropus & 28 & 8.41 \\
\hline 7 & Rallidae & Ballion's crake & Porzana pusilla & 11 & 3.30 \\
\hline 8 & Charadriidae & Red-wattled lapwing & Vanellus indicus & 8 & 2.40 \\
\hline 9 & Jacanidae & Pheasant-tailed jacana & Hydrophasianus chirurgus & 6 & 1.80 \\
\hline 10 & Rallidae & White-browed crake & Porzana cinerea & 5 & 1.50 \\
\hline 11 & Ardeidae & Grey heron & Ardea cinerea & 4 & 1.20 \\
\hline 12 & Ardeidae & Little heron & Butorides striatus & 3 & 0.90 \\
\hline 13 & Scolopacidae & Common sandpiper & Tringa. hypoleucos & 2 & 0.60 \\
\hline 14 & Podicipedidae & Little grebe & Tachybaptus ruficollis & 2 & 0.60 \\
\hline 15 & Alcidinidae & Common kingfisher & Alcedo atthis & 1 & 0.30 \\
\hline 16 & Anatidae & Cotton pygmy goose & Nettapus coromandelianus & 1 & 0.30 \\
\hline \multirow[t]{2}{*}{17} & Rallidae & Water cock & Gallicerx cinerea & 1 & 0.30 \\
\hline & & Total & & 333 & \\
\hline
\end{tabular}


TABLe 3: List of waterbird species with relative abundance recorded in Open Water Body at Paya Indah Natural Wetland Reserve, Peninsular Malaysia.

\begin{tabular}{|c|c|c|c|c|c|}
\hline Rank & Family name & Common name & Scientific name & No. of observations & $\%$ \\
\hline 1 & Anatidae & Lesser whistling duck & Dendrocygna javanica & 199 & 42.16 \\
\hline 2 & Anatidae & Cotton pygmy goose & Nettapus coromandelianus & 81 & 17.16 \\
\hline 3 & Alcidinidae & White-throated kingfisher & Halcyon smyrnensis & 42 & 8.90 \\
\hline 4 & Charadriidae & Red-wattled lapwing & Vanellus indicus & 41 & 8.69 \\
\hline 5 & Rallidae & Purple swamphen & Porphyrio porphyrio & 25 & 5.30 \\
\hline 6 & Rallidae & White-breasted waterhen & Amaurornis phoenicurus & 25 & 5.30 \\
\hline 7 & Ardeidae & Purple heron & Ardea purpurea & 22 & 4.66 \\
\hline 8 & Ardeidae & Yellow bittern & Ixobrychus sinensis & 11 & 2.33 \\
\hline 9 & Podicipedidae & Little Grebe & Tachybaptus ruficollis & 7 & 1.48 \\
\hline 10 & Ardeidae & Cinnamon bittern & Ixorbychus cinnamoneus & 6 & 1.27 \\
\hline 11 & Rallidae & Common moorhen & Gallinula chloropus & 6 & 1.27 \\
\hline 12 & Rallidae & Water cock & Gallicerx cinerea & 3 & 0.64 \\
\hline 13 & Scolopacidae & Pintail snipe & Gallinago stenura & 2 & 0.42 \\
\hline 14 & Ardeidae & Grey heron & Ardea cinerea & 1 & 0.21 \\
\hline \multirow[t]{2}{*}{15} & Ardeidae & Schrenck's bittern & Ixobrychus eurhythmus & 1 & 0.21 \\
\hline & & Total & & 472 & \\
\hline
\end{tabular}

TABle 4: Comparison of waterbird abundance in marsh swamp, open water body, and lotus swamp habitats at Paya Indah Natural Wetland Reserve, Peninsular Malaysia.

\begin{tabular}{lcc}
\hline Habitat name & $\begin{array}{c}\text { Mean waterbird } \\
\text { abundance }(\%)\end{array}$ & Standard error (SE) \\
\hline Marsh swamp & $118.27 \mathrm{a}$ & 0.37 \\
Open water body & $31.67 \mathrm{~b}$ & 1,06 \\
Lotus swamp & $21.40 \mathrm{~b}$ & 1.12 \\
\hline
\end{tabular}

(The mean values in columns with same letter are not significant at $P=$ $0.05)$.

was significantly different; that is, $F_{2,42}=68.42, P<0.05$ (Table 8 and Table 14).

3.7. Proportion and Type of Vegetation in Three Habitats. Marsh swamp habitat was densely covered with water chestnuts-E. dulcis (59.12\%), and lotus swamp habitat was densely covered with emergent vegetation that is water lilies-N. nucifera (55.40\%) while, open water body was with spike water-milfoils-M. spicatum, and common duck weeds-S. minima (61.50\% both). The edges were covered with grasses (Imperata cylindrical, S. olneyi, P. maximum and Distichlis spicata). However, some shrub that is, Melastoma malabathrcium, and Dillenia suffruticosa and tree species, that is, Acacia auriculiformis, Melicope glabra, Cinnamomum iners, Fragraea fragrans, and Macaranga tanarius were recorded along the edges of marsh swamp, open water body, and lotus swamp (Table 9).

3.8. Correlationship between Water Level and Waterbird Abundance. Pearson's correlation coefficient (PCC) was used to determine the correlationship between water level and waterbird abundance. The results of PCC test showed a weak linear correlationship between water level and waterbird abundance in lotus swamp habitat $\left(r^{2}=0.120, P>0.05\right)$ and in Marsh Swamp habitat $\left(r^{2}=0.100, P>0.05\right)$. In contrast, negative linear correlationship $\left(r^{2}=-0.710, P>0.05\right)$ was recorded between water level and waterbird abundance in open water body habitat.

3.9. Correlation between Waterbirds and Vegetation in Marsh Swamp Habitat. Canonical correspondence analysis (CCA) was used to examine the correlationship between waterbird abundance and vegetation type in marsh swamp habitat. The CCA analysis indicated that the correlationship between waterbird abundance and vegetation was (45.1\%) (Table 10).

The CCA ordination biplot diagram of marsh swamp habitat showed that purple swamphens, purple herons, yellow bitterns, and cinnamon bitterns have strong association with emergent vegetation, white-breasted waterhens and white-throated kingfishers had close relationship with grasses while, lesser whistling ducks, little grebes, and cotton pygmy geese had strong associated with submerged vegetation. In contrast, common moorhens and red-wattled lapwings showed negative association with emergent and submerged vegetation (Figure 6).

3.10. Correlation between Waterbirds and Vegetation in Lotus Swamp Habitat. The canonical correspondence analysis test indicated a weak correlationship between waterbird abundance and vegetation (29.8\%). This suggested that waterbird abundance in lotus swamp habitat a was little bit influenced by different vegetation namely, emergent vegetation, submerged vegetation, grasses, shrubs, and trees (Table 11).

The CCA ordination biplot diagram of lotus swamp habitat showed that common moorhen, grey heron, and pheasant-tailed jacanas have association with emergent vegetation, white-breasted waterhens, yellow bitterns, ballion's crakes, and purple swamphens have positive correlationship 
TABle 5: Monthly water level (m) data in marsh swamp at Paya Indah Natural Wetland Reserve, Peninsular Malaysia.

\begin{tabular}{lccc}
\hline Months & Minimum water level (meters) & Mean water level (meters) & Maximum water level (meters) \\
\hline November, 2007 & 2.218 & 2.249 & 2.273 \\
December, 2007 & 2.206 & 2.222 & 2.237 \\
January, 2008 & 2.197 & 2.243 & $2.313 \uparrow$ \\
February, 2008 & 2.176 & 2.197 & 2.218 \\
March, 2008 & 2.197 & 2.215 & 2.231 \\
April, 2008 & 2.246 & 2.218 & 2.237 \\
May, 2008 & 2.167 & 2.182 & 2.222 \\
June, 2008 & 2.139 & 2.151 & 2.167 \\
July, 2008 & 2.127 & 2.148 & 2.167 \\
August, 2008 & 2.084 & 2.103 & 2.127 \\
September, 2008 & 2.075 & 2.097 & 2.115 \\
October, 2008 & $2.048 \downarrow$ & 2.090 & 2.124 \\
November, 2008 & 2.087 & 2.112 & 2.154 \\
December, 2008 & 2.142 & 2.167 & 2.185 \\
January, 2009 & 2.151 & 2.170 & 2.182 \\
\hline
\end{tabular}

Note: $\uparrow$ Arrow show maximum water level and $\downarrow$ arrow shows minimum water level.

TABLE 6: Monthly water level (m) data in open water body at Paya Indah Natural Wetland Reserve, Peninsular Malaysia.

\begin{tabular}{lccc}
\hline Months & Minimum water level (meters) & Mean water level (meters) & Maximum water level (meters) \\
\hline November, 2007 & 2.514 & 2.535 & 2.554 \\
December, 2007 & 2.502 & 2.529 & 2.557 \\
January, 2008 & 2.526 & 2.548 & $2.572 \uparrow$ \\
February, 2008 & 2.478 & 2.499 & 2.523 \\
March, 2008 & 2.502 & 2.542 & 2.569 \\
April, 2008 & 2.532 & 2.523 & 2.572 \\
May, 2008 & 2.499 & 2.526 & 2.554 \\
June, 2008 & 2.459 & 2.526 & 2.493 \\
July, 2008 & 2.453 & 2.465 & 2.475 \\
August, 2008 & 2.426 & 2.438 & 2.453 \\
September, 2008 & 2.417 & 2.438 & 2.456 \\
October, 2008 & 2.432 & 2.438 & 2.462 \\
November, 2008 & 2.401 & 2.420 & 2.444 \\
December, 2008 & 2.420 & 2.441 & 2.459 \\
January, 2009 & $2.398 \downarrow$ & 2.423 & 2.441 \\
\hline
\end{tabular}

Note: $\uparrow$ Arrow shows maximum water level and $\downarrow$ arrow shows minimum water level.

with grasses. On contrary, white-browed crakes and redwattled lapwings had negative association with shrubs, submerged vegetation, grasses, and trees (Figure 7).

The results of canonical correspondence analysis (CCA) of open water body habitat showed that waterbird abundance had strong association with vegetation $(73.0 \%)$. Hence, this revealed that vegetation types, that is, emergent vegetation, submerged vegetation, grasses, shrubs, and trees, influence waterbird distribution (Table 12).

The CCA ordination biplot diagram of open water body habitat indicated that white-breasted waterhens, cinnamon bitterns, white-throated kingfisher and yellow bittern had close association with emergent vegetation and trees. Like- wise, lesser whistling ducks and little grebe had strong correlationship with submerged vegetation and shrubs. in contrast, red-wattled lapwing and common moorhens showed negative association with submerged vegetation, shrubs, and emergent vegetation. Furthermore, cotton pygmy geese showed positive correlationship with grasses (Figure 8).

\section{Discussions}

The attraction and response of waterbirds in relation to water level is conspicuous and reflects the status of habitat at a given time of a particular area. Apparently, this wetland reserve straddles the water resources from Sungai Chua and 
TABle 7: Monthly water level (m) data in lotus swamp at Paya Indah Natural Wetland Reserve, Peninsular Malaysia.

\begin{tabular}{lccr}
\hline Months & Minimum water level (meters) & Mean water level (meters) & Maximum water level (meters) \\
\hline November, 2007 & 2.188 & 2.215 & 2.237 \\
December, 2007 & 2.182 & 2.203 & 2.228 \\
January, 2008 & 2.185 & 2.215 & 2.182 \\
February, 2008 & 2.090 & 2.130 & 2.222 \\
March, 2008 & 2.118 & 2.179 & 2.228 \\
April, 2008 & 2.185 & 2.026 & 2.215 \\
May, 2008 & 2.060 & 2.145 & 2.072 \\
June, 2008 & 1.865 & 1.966 & 1.889 \\
July, 2008 & 1.859 & 1.883 & 1.868 \\
August, 2008 & 1.841 & 1.853 & 1.868 \\
September, 2008 & 1.837 & 1.856 & 1.895 \\
October, 2008 & $1.834 \downarrow$ & 1.868 & 1.935 \\
November, 2008 & 1.874 & 1.895 & 2.005 \\
December, 2008 & 1.932 & 1.978 & 1.993 \\
January, 2009 & 1.978 & 2.008 & \\
\hline
\end{tabular}

Note: $\uparrow$ Arrow shows maximum water level and $\downarrow$ arrow shows minimum water level.

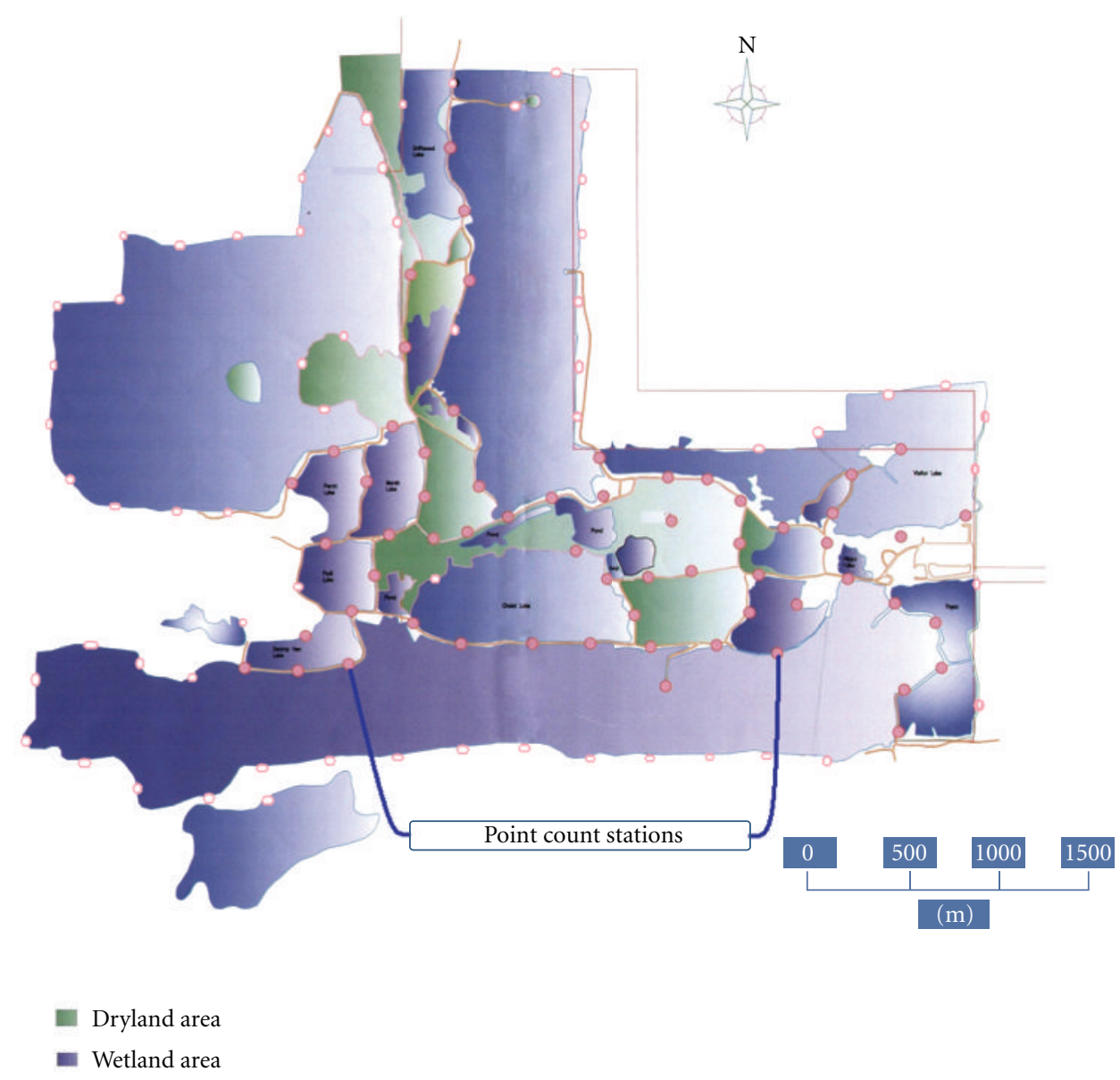

FIgURE 5: Map location of the distance sampling point count stations at Paya Indah Natural Wetland Reserve, Peninsular Malaysia. 
TABle 8: Comparison of mean water level of marsh swamp, open water body, and lotus swamp at Paya Indah Natural Wetland Reserve, Peninsular Malaysia.

\begin{tabular}{lcc}
\hline Habitat name & $\begin{array}{c}\text { Mean water level } \\
(\text { meters })\end{array}$ & $\begin{array}{c}\text { Standard error } \\
(\mathrm{SE} \pm)\end{array}$ \\
\hline Marsh swamp & $2.48 \mathrm{a}$ & 0.06 \\
Open water body & $2.19 \mathrm{~b}$ & 0.05 \\
Lotus swamp & $2.03 \mathrm{c}$ & 0.16 \\
\hline
\end{tabular}

(The mean values in columns with same letter are not significant at $P=$ 0.05$,$) .$

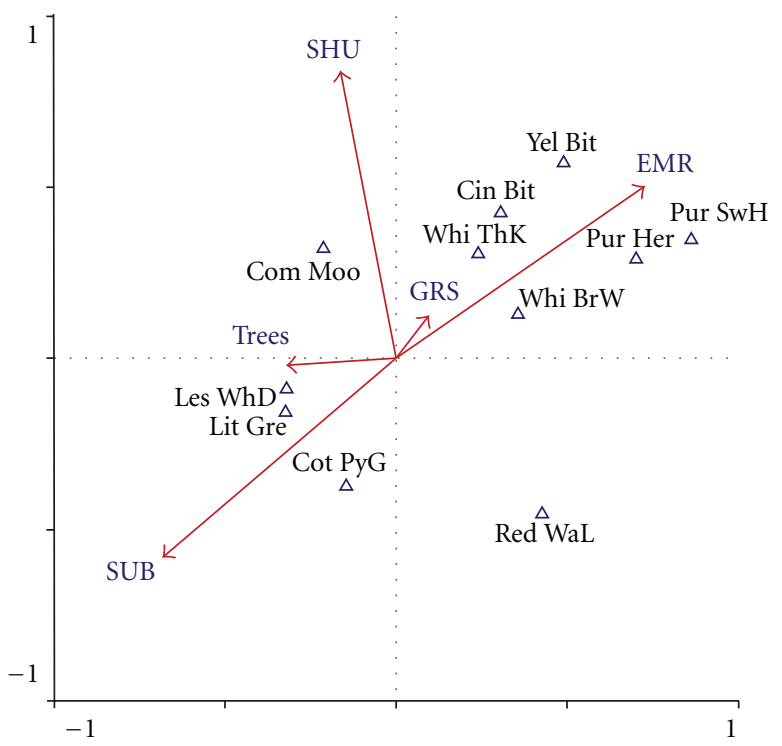

Figure 6: Ordination plot from a canonical correspondence analysis of waterbirds abundance of Marsh Swamp in relation to vegetation type. The biplot of axes 1 and 2 is presented; the orientation of each vegetation type in relation to waterbird is presented by an arrow, and the length of arrow indicates the degree of correlation.

Sungai Bisa. It was observed that the water levels in this natural wetland reserve might vary during 15 consecutive months due to unpredictable hydrological events such as rainfall and incoming water resources from the watershed areas of Sungai Chua and Sungai Bisa. It also has been reported that water level in wetlands might vary depending upon incoming water resources and precipitation [22-24].

It was observed that the changes in water level had eventually caused a shift of aquatic vegetation in the study area for instance, and when the water level went down, the shallow water areas which were dominated by water chestnuts (E. dulcis), marsh sedges (S. purpurascens), woolly water lilies (P. lanuginosum), spike water-milfoils $(M$. spicatum), and smooth cord grass (S. alterniflora) became dry and suppressed by grasses such as cogon grass ( $I$. cylindrical), three square bulrushes (S. olneyi), buffalo grass (P. maximum), spike grass (D. spicata) and carpet grass (Cynodon dactylon). Due to decrease in water level, the lotus (N. nucifera) became dry and was replaced by emergent vegetation that is, E. dulcis and S. purpurascens. Mortsch [25]

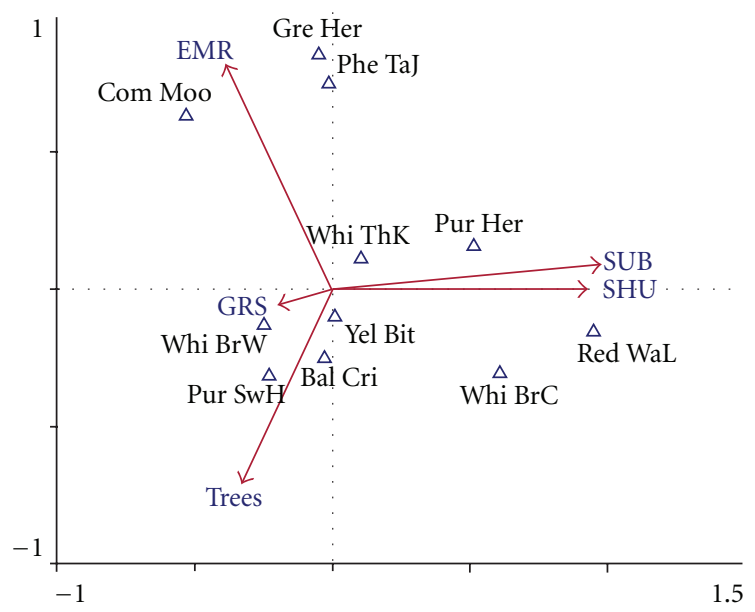

Figure 7: Ordination plot from a canonical correspondence analysis of waterbirds abundance of lotus swamp in relation to vegetation type. The biplot of axes 1 and 2 is presented; the orientation of each vegetation type in relation to waterbird is presented by an arrow, and the length of arrow indicates the degree of correlation.

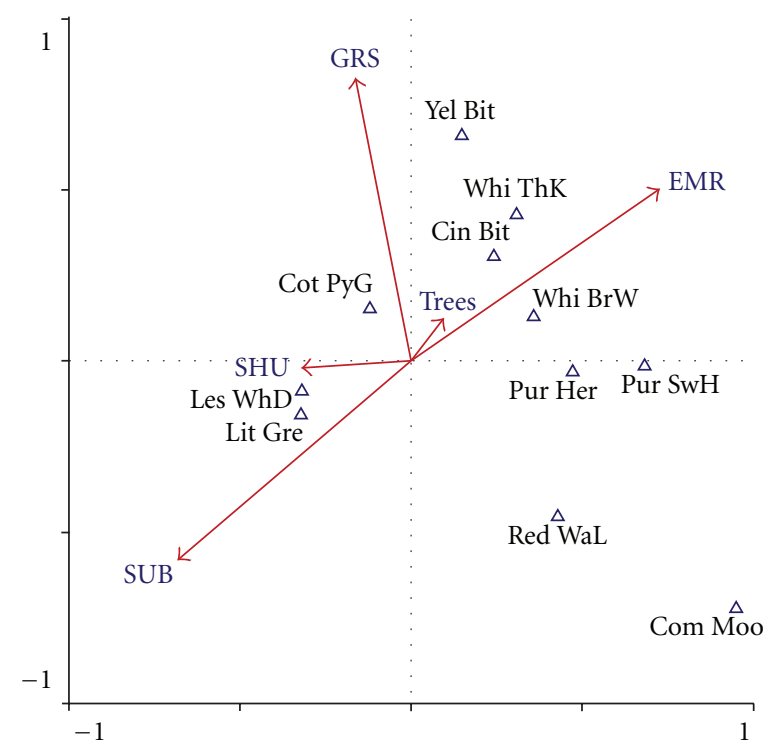

FIgURE 8: Ordination plot from a canonical correspondence analysis of waterbirds abundance of open water body in relation to vegetation type. The biplot of axes 1 and 2 is presented; the orientation of each vegetation type in relation to waterbird is presented by an arrow, and the length of arrow indicates the degree of correlation.

and Poiani et al. [26] has also reported that lower water level caused the changes in aquatic vegetation composition and structures and as a result, affected the grass and shrub communities.

In addition, when water level rose, the areas that were dominated by emergent vegetation sank and the lotus plants became dominant species. These changes in vegetation composition had caused the shift of ducks, swamphens, crakes, herons, jacanas, and moorhens from deeper areas 
TABLE 9: The proportion and type of vegetation occurring in three habitats at Paya Indah Wetland Reserve, Peninsular Malaysia.

\begin{tabular}{lccc}
\hline Type of vegetation & Marsh swamp & Lotus swamp & Open water body \\
\hline Emergent vegetation (EMR) & $59.12 \%$ & $55.40 \%$ & $30.80 \%$ \\
Submerged vegetation (SUB) & $13.61 \%$ & $15.40 \%$ & $61.50 \%$ \\
Grasses (GRS) & $4.82 \%$ & $5.00 \%$ & $4.54 \%$ \\
Shrubs (SHU) & $3.74 \%$ & $1.20 \%$ & $3.16 \%$ \\
Trees & 67 & 17 & 6 \\
\hline
\end{tabular}

TABLE 10: Summary table of CCA coordination for waterbird abundance and vegetation type in marsh swamp habitat at Paya Indah Wetland Reserve, Peninsular Malaysia.

\begin{tabular}{|c|c|c|c|c|c|}
\hline \multirow{2}{*}{ Term } & \multicolumn{5}{|c|}{ Axis } \\
\hline & 1 & 2 & 3 & 4 & Total \\
\hline Eigen values & 0.226 & 0.093 & 0.075 & 0.043 & 1.069 \\
\hline Species-environmental correlations & 0.938 & 0.817 & 0.687 & 0.706 & - \\
\hline Cumulative percentage variance of species data & 21.2 & 29.8 & 36.9 & 40.9 & - \\
\hline Cumulative percentage variance of species-environment relation & 50.1 & 70.7 & 87.4 & 97.0 & - \\
\hline Sum of all eigen values & - & - & - & - & 1.069 \\
\hline Sum of all canonical eigen values & - & - & - & - & 0.451 \\
\hline
\end{tabular}

to shallow waters such as edges dominated by emergent vegetation. Birds often relate to vegetation community, thus, shifts in vegetation may influence the distribution of bird species [27]. In the study, it was also observed that due to the rise in water level, the swamphens moved to shallow areas covered with emergent vegetation such as water chestnuts, sometimes flew to the deep-water area to pluck the seeds of water lilies, and then flew to the dryland and consumed there. Furthermore, ducks also moved to water bodies having emergent vegetation along the edges, because they provide suitable loafing sites for them. The shallow vegetated areas are rich in food sources such as fishes, amphibians, and aquatic invertebrates. The rise in water level affects the abundance and distribution of invertebrate, amphibian, and fish compositions which were the main sources of food for the waterbirds. This shows that fluctuation in water level within wetland indicates where and when waterbird species can access their foods.

However, lapwings, waterhens, kingfishers, geese, grebes, and water cocks were less affected such as lapwing mostly utilized moist soil in ditches and along edges for foraging and dry land for breeding, waterhen and water cock preferred both water body edges and dry grassland adjacent to water bodies, kingfisher hunted on fishes and insects through sallying and consumed on trees, and grebes and geese often preferred deeper water for foraging. Seemingly, high water level can make invertebrate food resources less available for many waterbirds [28-30].

In contrast, when water level fall down, the leaves of water lilies became dry that caused shift in waterbird such as jacanas, bitterns, and moorhen moved to shallow waters dominated by water lilies and water chestnut vegetation. Jacanas foraged on snails and aquatic insects attached with floating leaves of water lilies, and bitterns sit on stems of water lily leaves and prey on aquatic insects resting or moving on aquatic vegetation or attached with leaves. This indicates that water level changes influence the physical structure of habitats (zonation of vegetation), the availability and accessibility of food, and the presence of safe roosting or breeding sites. Similar findings were also recorded by Green and Robins [31], Guillemain et al. [32], and Clausen [33]. Eventually, the fluctuation in water level might alter the habitat characteristics that could cause prompt changes in fish, amphibians, invertebrates and waterbird communities [34-38].

The results of this study indicated that water level is a major factor that influenced the waterbird species composition and relative abundance directly and indirectly in this wetland reserve. In addition, it was observed that waterbird abundance is influenced by water level and richness of aquatic vegetation, that is, water chestnut (E. dulcis), lotus (N. nucifera), marsh sedge (S. purpurascens), wooly water lily ( $P$. lanuginosum), spike water-milfoil ( $M$. spicatum), common duck weed (S. minima), and smooth cord grass ( $S$. alterniflora). Undeniably, it was also recorded that water level is a crucial factor that influenced the dynamics of aquatic vegetation composition.

It has been reported that the higher waterbird species diversity occurred at $0-20 \mathrm{~cm}$ water depths due to availability of diverse foraging sites, which might vary from exposed mud to deeper water with submerged aquatic plants [29, $30,39-41]$ and correlates to hydrological variation [22, 4244]. Causarano and Battisti [24] examined the effects of a seasonal water level on five water-obligated birds, that is, Tachybaptus ruficollis, Anas platyrhynchos, Rallus aquaticus, Gallinula chloropus, and Fulica atra and reported that the 
TABLE 11: Summary table of CCA coordination for waterbird and vegetation types in lotus swamp habitat at Paya Indah Wetland Reserve, Peninsular Malaysia.

\begin{tabular}{|c|c|c|c|c|c|}
\hline \multirow{2}{*}{ Term } & \multicolumn{5}{|c|}{ Axis } \\
\hline & 1 & 2 & 3 & 4 & Total \\
\hline Eigen values & 0.142 & 0.111 & 0.035 & 0.010 & 0.298 \\
\hline Species-environmental correlations & 1.000 & 1.000 & 1.000 & 1.000 & - \\
\hline Cumulative Percentage variance of species data & 47.7 & 84.9 & 96.6 & 100.0 & - \\
\hline Cumulative Percentage variance of species-environment relation & 47.7 & 84.9 & 96.6 & 100.0 & - \\
\hline Sum of all eigen values & - & - & - & - & 0.298 \\
\hline Sum of all canonical eigen values & - & - & - & - & 0.298 \\
\hline
\end{tabular}

TABLE 12: Summary table of CCA coordination for waterbird abundance and vegetation type in open water body at Paya Indah Wetland Reserve, Peninsular Malaysia.

\begin{tabular}{|c|c|c|c|c|c|}
\hline \multirow{2}{*}{ Term } & \multicolumn{5}{|c|}{ Axis } \\
\hline & 1 & 2 & 3 & 4 & Total \\
\hline Eigen values & 0.414 & 0.199 & 0.072 & 0.030 & 0.730 \\
\hline Species-environmental correlations & 1.000 & 1.000 & 1.000 & 1.000 & - \\
\hline Cumulative Percentage variance of species data & 56.7 & 83.9 & 93.9 & 98.0 & - \\
\hline Cumulative Percentage variance of species-environment relation & 56.7 & 83.9 & 93.9 & 98.0 & - \\
\hline Sum of all eigen values & - & - & - & - & 0.730 \\
\hline Sum of all canonical eigen values & - & - & - & - & 0.730 \\
\hline
\end{tabular}

TABle 13: Analysis of variance (ANOVA) of waterbird abundance of three habitats, namely, marsh swamp, open water body, and lotus swamp at Paya Indah Natural Wetland Reserve, Peninsular Malaysia.

\begin{tabular}{lcccc}
\hline DF & SS & MS & $F$ & $P$ \\
\hline 2 & 84940.6 & 42470.3 & 226.20 & 0.0000 \\
42 & 7885.87 & 187.759 & - & - \\
44 & 92826.4 & - & - & - \\
\hline
\end{tabular}

reduction in water depth dried out the reed beds and rush beds that consequently reduced the habitat suitability. In addition, Boertmann and Riget [45] studied the effects of water level fluctuation on dabbling ducks and found that eurasian wigeons (Anas PenelopeI), eurasian teals (Anas crecca), and mallards (Anas platyrhynchosI) positively correlated with the water level while northern shovelors (Anas clypeata) and northern pintails (Anas acuta) showed less evidence of correlationship with the water level.

Additionally, DesGranges et al. [46] examined the wetland birds' response to water level fluctuation and revealed that wetland bird species were significantly associated with hydrological context. Additionally, Hamabata [47] and Sugawa [48] also reported that the waterbird species richness was usually high in shallow waters less than $3 \mathrm{~m}$ deep with gentle slopes. Furthermore, Epstein and Joyner [49] and Colwell and Taft [41] reported that maximum waterbird abundance occurred at zero water depth. On the other hand, Hands et al. [50] and Frederick and McGehee [51] compared the bird relative abundance among wetlands and found confounding effects of variation in water depth.
TABle 14: Analysis of variance (ANOVA) of mean water levels of three habitats, namely, marsh swamp, open water body and lotus swamp at Paya Indah Natural Wetland Reserve, Peninsular Malaysia.

\begin{tabular}{lcccc}
\hline DF & SS & MS & $F$ & $P$ \\
\hline 2 & 1.54 & 0.77 & 68.42 & 0.0000 \\
42 & 0.47 & 0.01 & - & - \\
44 & 2.01 & - & - & - \\
\hline
\end{tabular}

\section{Conclusion}

The results of this study indicate that water level is a major factor that influenced the relative abundance and distribution of ducks, swamphen, crakes, herons, jacanas, and moorhens directly and indirectly. In addition, it also affects the dynamics of aquatic vegetation composition such as emergent, submerged, and grasses in this wetland reserve.

\section{Appendix}

For more details, see Tables 13 and 14.

\section{Contribution of the Main Author}

M. N. Rajpar developed the experimental design, collected and analyzed the data, and also wrote of the paper. M. Zakaria reviewed and edited the paper.

\section{Acknowledgments}

The authors would like to thank Department of Wildlife and National Parks, Peninsular Malaysia, for allowing conducting 
this research study at Paya Indah Natural Wetland Reserve. This research was partially funded by Fundamental Grant Research Scheme 01-10-07-291FR and Forestry Sector Research Division Project, Pakistan Forest Institute, Peshawar, Pakistan.

\section{References}

[1] F. M. Yusoff, M. Shariff, and N. Gopinath, "Diversity of Malaysian aquatic ecosystems and resources," Aquatic Ecosystem Health and Management, vol. 9, no. 2, pp. 119-135, 2006.

[2] M. N. Rajpar and M. Zakaria, "Assessment of waterbirds at Paya Indah Wetland Reserve, Peninsular Malaysia," in Proceedings of the UTM 8th Annual Symposium on Sustainability Science and Management, pp. 606-612, Kuala Terengganu, Peninsular Malaysia, Malaysia, March 2009.

[3] G. M. Siriwardena, S. R. Baillie, S. T. Buckland, R. M. Fewster, J. H. Marchant, and J. D. Wilson, "Trends in the abundance of farmland birds: a quantitative comparison of smoothed common birds census indices," Journal of Applied Ecology, vol. 35, no. 1, pp. 24-43, 1998.

[4] J. R. Krebs, J. D. Wilson, R. B. Bradbury, and G. M. Siriwardena, "The second silent spring?" Nature, vol. 400, no. 6745, pp. 611-612, 1999.

[5] J. A. Kushlan, "Responses of wading birds to seasonally fluctuating water levels: strategies and their limits," Colonial Waterbirds, vol. 9, pp. 155-162, 1986.

[6] G. Catsadorakis, M. Malakou, and A. J. Crivelli, "The effects of the 1989/1990 drought on the colonial waterbirds nesting at Lake Mikri Prespa, Greece, with special emphasis on Pelicans," Waterbirds, vol. 19, no. 1, pp. 207-218, 1996.

[7] M. D. Sanders, "Effect of changes in water level on numbers of black stilts (Himantopus novaezelandiae) using deltas of Lake Benmore," New Zealand Journal of Zoology, vol. 26, no. 2, pp. 155-163, 1999.

[8] M. Pyrovetsi and E. Papastergiadou, "Biological conservation implications of water-level fluctuations in a wetland of international importance: Lake Kerkini, Macedonia, Greece," Environmental Conservation, vol. 19, no. 3, pp. 235-243, 1992.

[9] A. J. Crivelli, P. Grillas, H. Jerrentrup, and T. Nazirides, "Effects on fisheries and waterbirds of raising water levels at Kerkini Reservoir, a Ramsar site in Northern Greece," Environmental Management, vol. 19, no. 3, pp. 431-443, 1995.

[10] A. Hattori and S. Mae, "Habitat use and diversity of waterbirds in a coastal lagoon around Lake Biwa, Japan," Ecological Research, vol. 16, no. 3, pp. 543-553, 2001.

[11] M. R. Kaminski, G. A. Baldassarre, and A. T. Pearse, "Waterbird responses to hydrological management of wetlands reserve program habitats in New York," Wildlife Society Bulletin, vol. 34, no. 4, pp. 921-926, 2006.

[12] M. Codesido and D. N. Bilenca, "Comparación de los métodos de transecta de fajay de conteo de puntos de radio fijo en una comunidad de aves del bosque semiárido santiagueño," El Hornero, vol. 15, pp. 85-91, 2000.

[13] C. J. Ralph, J. R. Sauer, and S. Droege, "Monitoring bird populations by point counts," Tech. Rep. PSW-GTR-149, Pacific Southwest Research Station, Forest Service, U.S. Department of Agriculture, Albany, Calif, USA, 1995.

[14] P. B. Hamel, W. P. Smith, D. J. Twedt et al., "A land manager's guide to point counts of birds in the Southeast," Tech. Rep. SO-120, Southern Experimental Station, Forest Service, US. Department of Agriculture, Asheville, NC, USA, 1996, http://www.dodpif.org/downloads/point-counts-SE.pdf.
[15] T. R. Mills, M. A. Rumble, and L. D. Flake, "Habitat of birds in Ponderosa pine and aspen/birch forest in the Black Hills, South Dakota," Journal of Field Ornithology, vol. 71, no. 2, pp. 187-206, 2000.

[16] W. P. Smith, D. J. Twedt, D. A. Wiedenfeld, P. B. Hamel, R. P. Ford, and R. J. Cooper, "Point counts of birds in Bottomland Hardwood Forests of the Mississippi Alluvial Valley: duration, minimum sample size, and points versus visits," Research Paper SO-274, USDA, Forest Service, Southern Forest Experiment Station, Diane Publishing Co, New Orleans, La, USA, 1993.

[17] D. R. Petit, L. J. Petit, V. A. Saab, and T. E. Martin, "Fixed radius point counts in forests: factors influencing effectiveness and efficiency," in Monitoring Bird Populations by Point Counts, C. J. Ralph, J. R. Sauer, and S. Droege, Eds., pp. 49-56, Diane Publishing Co., New Orleans, La, USA, 1995, USDA, Forest Service, Research Paper SO-274, Southern Forest Experiment Station.

[18] S. T. Buckland, D. R. Anderson, K. P. Burnhan, J. L. Lake, D. L. Borchers, and L. Thomas, Advance Distance Sampling; Estimating Abundance of Biological Populations, Campman and Hall, London, UK, 2004.

[19] D. A. Aborn, "Abundance, density, and diversity of neotropical migrants at the Lula Lake Land Trust, GA," Southeastern Naturalist, vol. 6, no. 2, pp. 293-304, 2007.

[20] C. P. Nadeau, C. J. Conway, B. S. Smith, and T. E. Lewis, "Maximizing detection probability of wetland-dependent birds during point-count surveys in Northwestern Florida," Wilson Journal of Ornithology, vol. 120, no. 3, pp. 513-518, 2008.

[21] C. J. F. T. Braak and P. Smilauer, "Canoco reference manual and canoco draw for windows user's guide: software for canonical ordination (Version 4.5)," Ithaca Press, New York, NY, USA, 2002.

[22] T. E. Holm and P. Clausen, "Effects of water level management on autumn staging waterbird and macrophyte diversity in three Danish coastal lagoons," Biodiversity and Conservation, vol. 15, no. 14, pp. 4399-4423, 2006.

[23] F. Bolduc and A. D. Afton, "Monitoring waterbird abundance in wetlands: the importance of controlling results for variation in water depth," Ecological Modelling, vol. 216, no. 3-4, pp. 402-408, 2008.

[24] F. Causarano and C. Battisti, "Effect of seasonal water level decrease on a sensitive bird assemblage in a Mediterranean wetland," Rendiconti Lincei, vol. 20, no. 3, pp. 211-218, 2009.

[25] L. D. Mortsch, "Assessing the impact of climate change on the Great Lakes shoreline wetlands," Climatic Change, vol. 40, no. 2, pp. 391-416, 1998.

[26] K. A. Poiani, W. C. Johnson, and T. G. F. Kittel, "Sensitivity of a prairie wetland to increased temperature and seasonal precipitation changes," Water Resources Bulletin, vol. 31, no. 2, pp. 283-294, 1995.

[27] D. A. Wolcox and J. E. Meeker, "Implications for faunal habitat related to altered macrophyte structure in regulated lakes in Northern Minnesota," Wetlands, vol. 12, no. 3, pp. 192-203, 1992.

[28] H. R. Murkin and J. A. Kadlec, "Relationships between waterfowl and macroinvertebrate densities in a Northern Prairie Marsh," Journal of Wildlife Management, vol. 50, no. 2, pp. 212-217, 1986.

[29] R. J. Safran, C. R. Isola, M. A. Colwell, and O. E. Williams, "Benthic invertebrates at foraging locations of nine waterbird species in managed wetlands of the Northern San Joaquin Valley, California," Wetlands, vol. 17, no. 3, pp. 407-415, 1997. 
[30] C. R. Isola, M. A. Colwell, O. W. Taft, and R. J. Safran, "Interspecific differences in habitat use of shorebirds and waterfowl foraging in managed wetlands of California's San Joaquin Valley," Waterbirds, vol. 23, no. 2, pp. 196-203, 2000.

[31] R. E. Green and M. Robins, "The decline of the ornithological importance of the somerset levels and moors, England and changes in the management of water levels," Biological Conservation, vol. 66, no. 2, pp. 95-106, 1993.

[32] M. Guillemain, S. Houte, and H. Fritz, "Activities and food resources of wintering teal (Anas crecca) in a diurnal feeding site: a case study in Western France," Revue d'Ecologie, vol. 55, no. 2, pp. 171-181, 2000.

[33] P. Clausen, "Modelling water level influence on habitat choice and food availability for Zostera feeding Brent geese Branta bernicla in non-tidal areas," Wildlife Biology, vol. 6, no. 2, pp. 75-87, 2000.

[34] J. R. Rey, R. A. Crossman, and T. R. Kain, "Vegetation dynamics in impounded marshes along the Indian River Lagoon, Florida, USA," Environmental Management, vol. 14, no. 3, pp. 397-409, 1990.

[35] P. A. Schmalzer, "Biodiversity of saline and brackish marshes of the Indian River Lagoon: historic and current patterns," Bulletin of Marine Science, vol. 57, no. 1, pp. 37-48, 1995.

[36] R. E. Brockmeyer, J. R. Rey, R. W. Virnstein, R. G. Gilmore, and L. Earnest, "Rehabilitation of impounded estuarine wetlands by hydrologie reconnection to the Indian River Lagoon, Florida (USA)," Wetlands Ecology and Management, vol. 4, no. 2, pp. 93-109, 1997.

[37] A. G. van der Walk, The Biology of Freshwater Wetlands, Oxford University Press, Oxford, UK, 2006.

[38] K. G. Johnson, M. S. Allen, and K. E. Havens, "A review of littoral vegetation, fisheries, and wildlife responses to hydrologic variation at Lake Okeechobee," Wetlands, vol. 27, no. 1, pp. 110-126, 2007.

[39] L. M. Weber and S. M. Haig, "Shorebird use of South Carolina managed and natural coastal wetlands," Journal of Wildlife Management, vol. 60, no. 1, pp. 73-82, 1996.

[40] C. S. Elphick and L. W. Oring, "Winter management of Californian rice fields for waterbirds," Journal of Applied Ecology, vol. 35, no. 1, pp. 95-108, 1998.

[41] M. A. Colwell and O. W. Taft, "Waterbird communities in managed wetlands of varying water depth," Waterbirds, vol. 23, no. 1, pp. 45-55, 2000.

[42] F. Bolduc and A. D. Afton, "Relationships between wintering waterbirds and invertebrates, sediments and hydrology of coastal marsh ponds," Waterbirds, vol. 27, no. 3, pp. 333-341, 2004.

[43] R. T. Kingsford, K. M. Jenkins, and J. L. Porter, "Imposed hydrological stability on lakes in arid Australia and effects on waterbirds," Ecology, vol. 85, no. 9, pp. 2478-2492, 2004.

[44] D. Robertson and T. Massenbauer, "Applying hydrological thresholds to wetland management for waterbirds using bathymetric surveys and GIS," in MODSIM 2005 International Congress on Modelling and Simulation, A. Zerger and R. M. Argent, Eds., pp. 2407-2413, Modelling and Simulation Society of Australia and New Zealand, Australia, 2005.

[45] D. Boertmann and F. Riget, "Effects of changing water levels on numbers of staging dabbling ducks in a Danish wetland," Waterbirds, vol. 29, no. 1, pp. 1-8, 2006.

[46] J. L. Desgranges, J. Ingram, B. Drolet, J. Morin, C. Savage, and D. Borcard, "Modelling wetland bird response to water level changes in the Lake Ontario-St. Lawrence River hydrosystem," Environmental Monitoring and Assessment, vol. 113, no. 1-3, pp. 329-365, 2006.
[47] E. Hamabata, "Biwa-ko no chinsuisyokubutu no bunpu to chiiki-kubun," in Biwa-Ko Kogan No Keikan-Seitaigaku Teki Kubun, Lake Biwa Research Institute, Otsu, Japan, 1991.

[48] H. Sugawa, "Mizudori no bunpu-jyoukyou to chiiki- kubun," in Biwa-Ko Kogan No Keikan-Seitaigaku Teki Kubun, Lake Biwa Research Institute, Otsu, Japan, 1991.

[49] M. B. Epstein and R. L. Joyner, "Waterbirds use of brackish wetlands managed for waterfowl," in Proceedings of the Annual Conference of the South-Eastern Association of the Fish and Wildlife Agencies, vol. 42, pp. 476-490, 1988.

[50] H. M. Hands, M. R. Ryan, and J. W. Smith, "Migrant shorebird use of marsh, moist-soil, and flooded agricultural habitats," Wildlife Society Bulletin, vol. 19, no. 4, pp. 457-464, 1991.

[51] P. C. Frederick and S. M. McGehee, "Wading bird use of wastewater treatment wetlands in central Florida, USA," Colonial Waterbirds, vol. 17, no. 1, pp. 50-59, 1994. 

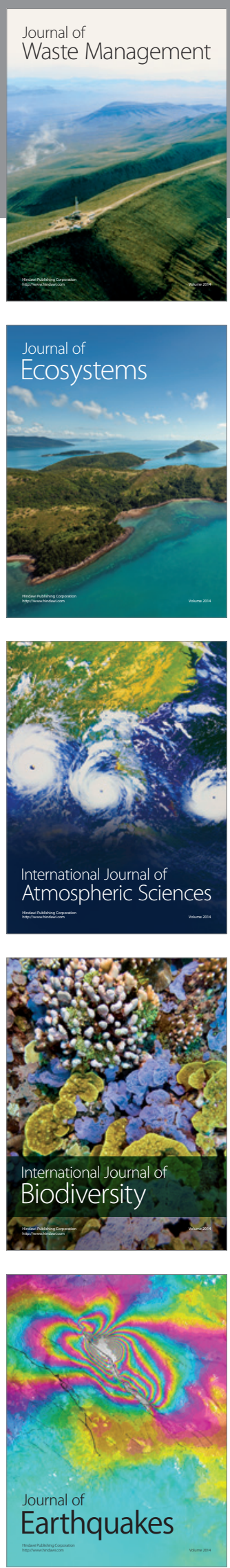
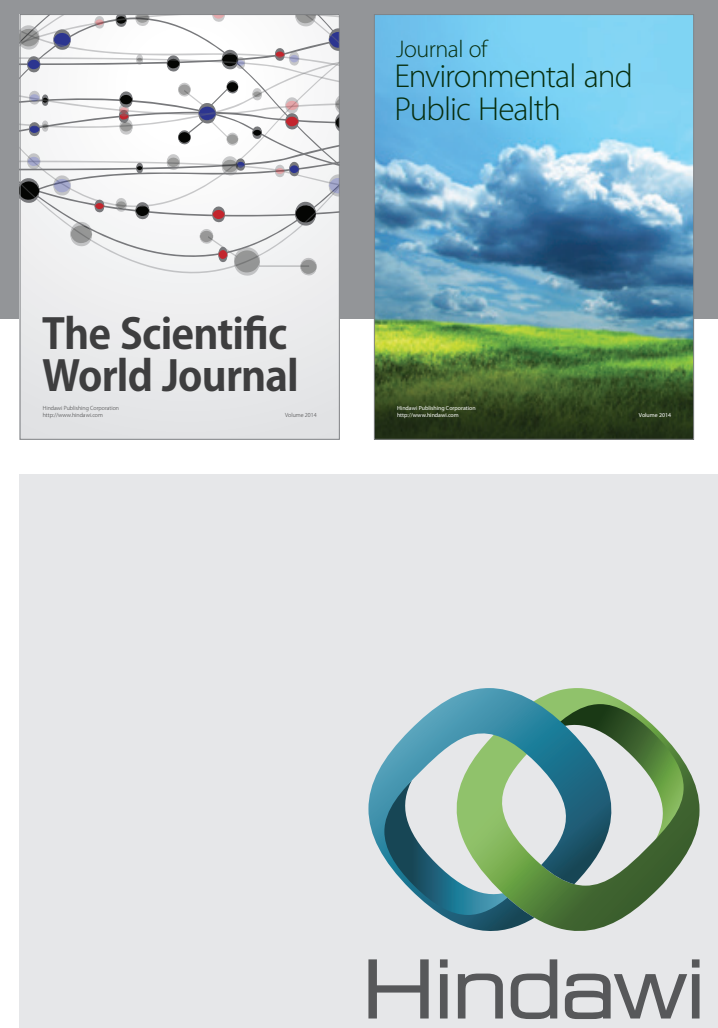

Submit your manuscripts at

http://www.hindawi.com
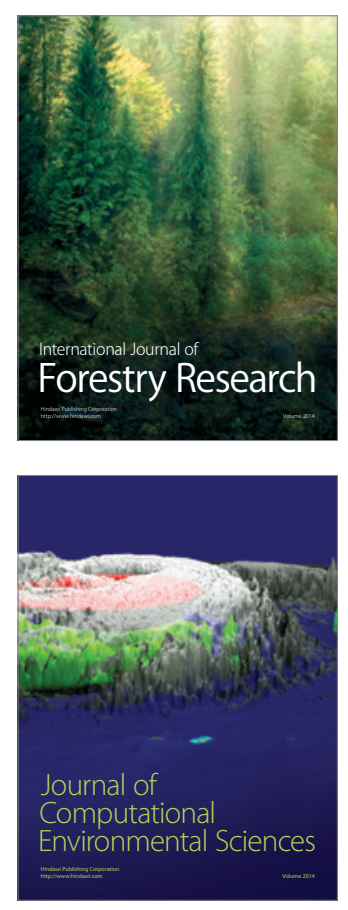
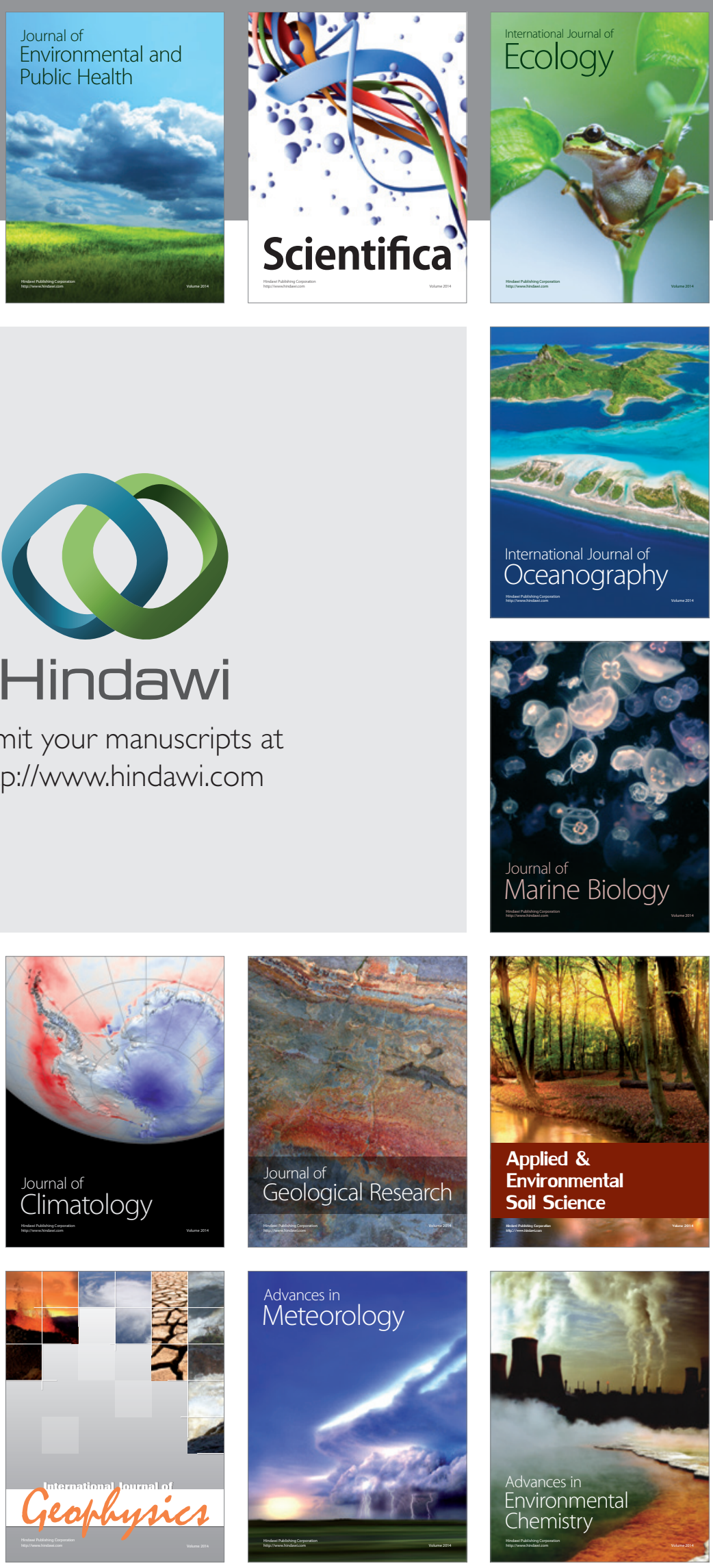